\title{
Selective impairment of growth hormone response to physiological stimuli
}

\author{
P. H. WISE, R. B. BURNET, T. D. GEARY, and HELEN BERRIMAN \\ Endocrine Unit, Royal Adelaide Hospital; and Biochemistry Division, Institute of \\ Medical and Veterinary Science, Adelaide, South Australia
}

Wise, P. H., Burnet, R. B., Geary, T. D., and Berriman, H. (1975). Archives of Disease in Childhood, 50, 210. Selective impairment of growth hormone response to physiological stimuli. In a consecutive group of 25 children with defective growth being evaluated for growth hormone deficiency, EEG-monitored slow-wave sleep provided discriminatory serum growth hormone responses equivalent to those obtained by arginine and insulin-hypoglycaemia provocation. Exercise was less effective but was able to provide a useful screening test.

In 2 subjects with abnormal physiological but normal pharmacological serum growth hormone responses, therapeutic administration of growth hormone in one resulted in a significant growth increment, whereas in the other, advanced epiphyseal maturity precluded adequate evaluation. A normal growth hormone response to a pharmacological stimulus does not exclude a therapeutic response to human growth hormone.

It has been claimed that the effectiveness of therapeutic human growth hormone (HGH) for enhancement of longitudinal growth is limited to children showing partial or complete growth hormone deficiency after pharmacological stimuli (Tanner et al., 1971). Accordingly, numerous methods for assessing growth hormone release have been evaluated, including insulin-induced hypoglycaemia (Roth et al., 1963), arginine infusion (Merrimee et al., 1967), levodopa (Weldon et al., 1973), and glucagon (Mitchell, Byrne, and Silver, 1969). Physiological stimuli to growth hormone release, namely exercise (Buckler, 1972) and slowwave sleep (Takahashi, Kipnis, and Daughaday, 1968), have also been identified.

In order to evaluate the use of physiological stimuli as relatively nontraumatic screening tests for $\mathrm{HGH}$ deficiency, and to determine whether short stature may be associated with normal pharmacological, but deficient physiological HGH responses, it has been the practice of this unit to evaluate $\mathrm{HGH}$ levels in response to simple intensive exercise, after the onset of slow-wave sleep, and with a standardized sequence of arginine and insulin-induced hypoglycaemic stimulation.

This report examines the correlation of these investigative methods and describes responses to

Received 29 July 1974.
HGH therapy in 2 children who achieved normal serum HGH levels with pharmacological stimuli, but in whom subnormal HGH levels were recorded with slow-wave sleep.

\section{Subjects}

Patients were considered eligible for complete growth hormone profile if their height was below the third centile for age (Tanner, Whitehouse, and Takaishi, 1966) and showed a growth velocity of less than $5 \mathrm{~cm} /$ year. 25 consecutive subjects conforming to these criteria were evaluated, excluding those with clearly defined syndromes such as gonadal dysgenesis, PraderWilli syndrome, etc. Ages ranged from 11 to 20 years and the final diagnoses are shown in the Table.

\section{Procedure}

After insertion of an indwelling antecubital venous catheter a consecutive arginine $(0.5 \mathrm{~g} / \mathrm{kg})$ and insulin hypoglycaemia (blood glucose $<50 \mathrm{mg} / 100 \mathrm{ml}$ and a $50 \%$ fall from fasting blood glucose) stimulation was induced, as described by Penny, Blizzard, and Davis (1969). Subjects were fed, and after a variable rest period were exercised to mild exhaustion by stair climbing, achieving pulse rates $>150 / \mathrm{min}$. A single growth hormone sample was taken 10 minutes after completion of exercise. On the same or occasionally on the previous evening no sedatives were prescribed, and depth of sleep (Dement and Kleitman, 1957) was monitored using Tektronix EEG/ECG monitor (Model 410), with two frontal electrodes, a single blood sample 
TABLE

Comparative growth hormone responses to pharmacological and physiological stimuli

\begin{tabular}{|c|c|c|c|c|c|c|c|}
\hline \multirow[b]{2}{*}{ Diagnosis } & \multirow[b]{2}{*}{ No. } & \multicolumn{4}{|c|}{ Serum growth hormone $(\mu \mathrm{U} / \mathrm{ml})$} & & \\
\hline & & \multicolumn{2}{|c|}{ Maximum arginine/insulin } & \multicolumn{2}{|c|}{ Slow-wave sleep } & \multicolumn{2}{|c|}{ Exercise } \\
\hline $\begin{array}{l}\text { Solitary HGH deficiency } \\
\text { Craniopharyngioma } \\
\text { Hypothalamic vascular } \\
\text { malformation } \\
\text { Toxoplasmosis } \\
\text { Delayed puberty } \\
\text { Chronic chest disease } \\
\text { Primary hypothyroidism } \\
\text { Diabetes mellitus } \\
\text { Anorexia nervosa } \\
\text { Case } 1 \text { (see text) } \\
\text { Case } 2 \text { (see text) }\end{array}$ & $\begin{array}{r}2 \\
2 \\
1 \\
1 \\
12 \\
2 \\
1 \\
1 \\
1\end{array}$ & $\begin{array}{r}6 \cdot 0 \\
2 \cdot 0 \\
9 \cdot 0 \\
6 \cdot 0 \\
36 \cdot 2 \\
50 \cdot 0 \\
27 \cdot 0 \\
19 \cdot 1 \\
24 \cdot 0 \\
30 \cdot 0 \\
50 \cdot 0\end{array}$ & 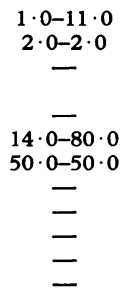 & $\begin{array}{r}3 \cdot 0 \\
2 \cdot 5 \\
10 \cdot 0 \\
5 \cdot 0 \\
33 \cdot 2 \\
43 \cdot 5 \\
25 \cdot 0 \\
36 \cdot 0 \\
39 \cdot 0 \\
9 \cdot 0 \\
6 \cdot 0\end{array}$ & 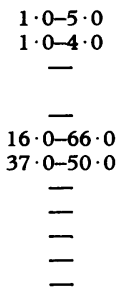 & $\begin{array}{l}2 \cdot 5 \\
2 \cdot 0 \\
10 \cdot 0 \\
2 \cdot 0 \\
19 \cdot 3 \\
18 \cdot 0 \\
11 \cdot 0 \\
21 \cdot 0 \\
35 \cdot 0 \\
12 \cdot 0 \\
15 \cdot 0\end{array}$ & $\begin{array}{c}1 \cdot 0-4 \cdot 0 \\
1 \cdot 0-3 \cdot 0 \\
- \\
- \\
2 \cdot 0-50 \cdot 0 \\
6 \cdot 0-30 \cdot 0 \\
= \\
= \\
=\end{array}$ \\
\hline
\end{tabular}

being taken 10 minutes after the onset of stage 4 (slowwave) sleep. This sample was taken either through the indwelling catheter or by a separate venepuncture, a procedure which usually but not always woke the patient. Onset of slow-wave sleep occurred within the time range 2130-0130 hours in an open ward situation.

\section{Methods}

Blood glucose was assayed by a glucose oxidase method using a Beckman Analyser; plasma cortisol by an adaptation of the competitive protein binding method of Murphy (1967); serum growth hormone by a double antibody immunoassay using the CEA-IRESORIN kit method. In each $\mathrm{HGH}$ assay high, medium, and low range quality control sera were included. The standard used is the Australian HGH Reference Standard BS 002 . The assay had a sensitivity of $1 \cdot 0$ $\mu \mathrm{U} / \mathrm{ml}$, with a precision (defined as $95 \%$ confidence limit for replicates) of \pm 0.9 at $9.0 \mu \mathrm{U} / \mathrm{ml}$. All the samples from any one patient were assayed within the same batch.

\section{Results}

An arbitrary lower limit of normal response of $14 \mu \mathrm{U} / \mathrm{ml}$ was used for evaluating all stimulation tests, derived from data and conclusions of Kaplan et al. (1968). On this basis, 18 subjects had a maximum arginine-insulin response exceeding this limit. In all but 2 (Cases 1 and 2) of these cases (Fig. 1), the slow-wave sleep sample also exceeded $14 \mu \mathrm{U} / \mathrm{ml}$. In 7 subjects, maximum arginineinsulin $\mathrm{HGH}$ levels were $<14.0 \mu \mathrm{U} / \mathrm{ml}$. In one of these sleep provoked a normal $(15 \cdot 3 \mu \mathrm{U} / \mathrm{ml})$ response, but in the remainder slow-wave sleep samples were also $<14 \mu \mathrm{U} / \mathrm{ml}$. In Cases 1 and 2, maximum arginine-insulin stimulated $\mathrm{HGH}$ levels of 30 and $50 \mu \mathrm{U} / \mathrm{ml}$, respectively, were obtained, compared with slow-wave sleep HGH levels of

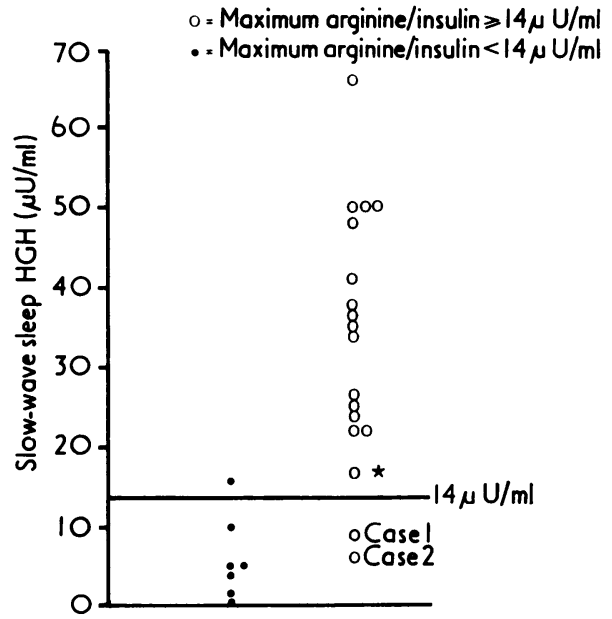

FIG. 1.-Comparison of slow-wave sleep uith arginine/ insulin-induced $H G H$ responses in short individuals with linear growth rates less than $5 \mathrm{~cm} /$ year. *See Addendum.

9 and $6 \mu \mathrm{U} / \mathrm{ml}$, respectively. These data are reported in detail below.

In the 18 subjects with normal arginine-insulin HGH responses, the mean ( \pm SEM) sleep-induced HGH level was $33 \cdot 1 \pm 3 \cdot 8 \mu \mathrm{U} / \mathrm{ml}$. This did not differ significantly from the maximal response to arginine-insulin stimulation $(35 \cdot 1 \pm 4 \cdot 6 \mu \mathrm{U} / \mathrm{ml})$, but exceeded that obtained with exercise $(19 \cdot 5 \pm$ $3.1 \mu \mathrm{U} / \mathrm{ml})$ to a significant degree $(\mathrm{t}=2 \cdot 47$; $P=0 \cdot 01)$. Only $9(50 \%)$ of those with maximum arginine-insulin $\mathrm{HGH}$ levels $>14 \mu \mathrm{U} / \mathrm{ml}$ had exercise levels also $>14 \mu \mathrm{U} / \mathrm{ml}$ (Fig. 2). In the 7 subjects with arginine-insulin HGH levels $<14$ $\mu \mathrm{U} / \mathrm{ml}$, all but one subject had exercise levels 


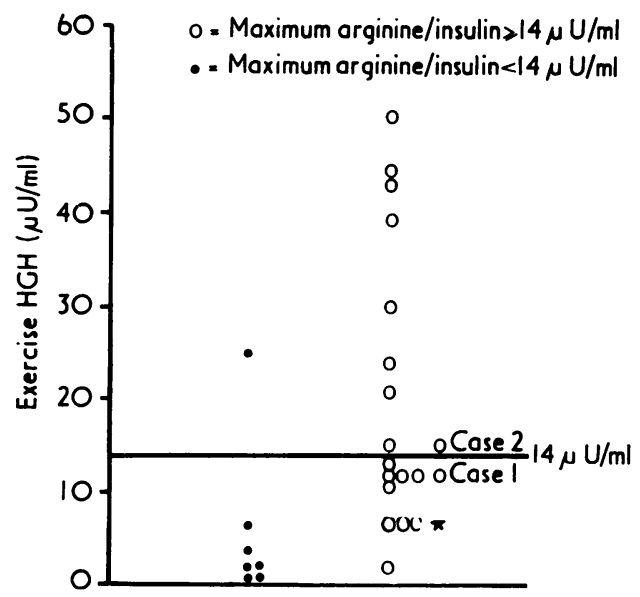

FIG. 2.-Comparison of exercise with arginine/insulininduced HGH responses in short individuals with linear growth rates less than $5 \mathrm{~cm} /$ year. * See Addendum.

$<14 \mu \mathrm{U} / \mathrm{ml}$. This subject, who had the normal sleep response referred to above, also had a clearly normal exercise $\mathrm{HGH}$ level of $25 \mu \mathrm{U} / \mathrm{ml}$, and on this basis was considered not to be growth hormone deficient. In Cases 1 and 2 exercise levels of 12 and $15 \mu \mathrm{U} / \mathrm{ml}$, respectively, were obtained.

Five of the pharmacologically demonstrable growth hormone-deficient children are currently receiving therapeutic $\mathrm{HGH}$ with growth velocity increments of 100 to $320 \%$.

Case 1. This male was referred originally at age 11.75 years for evaluation of short stature $(124.5 \mathrm{~cm})$. He had a birthweight of $2.7 \mathrm{~kg}$ and a birth length of $50 \mathrm{~cm}$ at 38 weeks of a normal gestation. He had normal milestones but had always been the smallest in school classes. Scholastically he was above average. Maternal and paternal heights were 164 and $165 \mathrm{~cm}$, respectively, and there was no family history of pubertal delay. Verified height measurements over 2 preceding years documented a growth velocity of $2.5 \mathrm{~cm} /$ year. Examination revealed symmetrical dwarfism; weight $22.4 \mathrm{~kg}$. Testicular size (Prader) was $2 \mathrm{ml}$, right and left. Serum thyroxine was $8.9 \mu \mathrm{g} / 100 \mathrm{ml}$ (normal $6 \cdot 0-12 \cdot 0$ ), bone age $6 \cdot 5$ years, at chronological age of $11 \cdot 25$ years and height age of $7 \cdot 4$ years.

Application for therapeutic $\mathrm{HGH}$ was not approved at this time because of maximum HGH levels of $37.5 \mu \mathrm{U} / \mathrm{ml}$ achieved during an insulin hypoglycaemia test (Fig. 3). Accordingly, in August 1972 a complete growth hormone profile
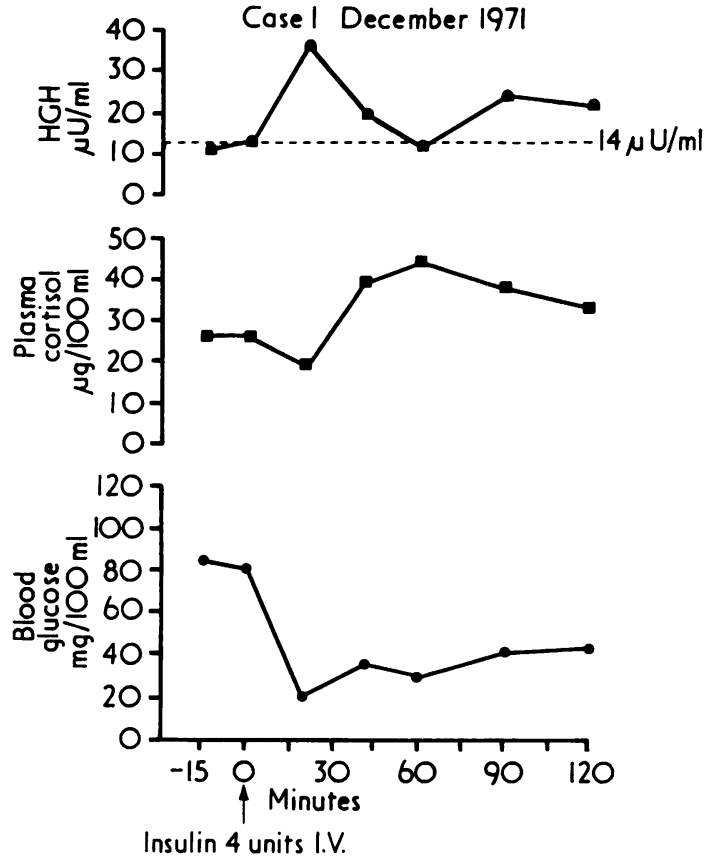

FIG. 3.-Initial insulin-hypoglycaemia test in Case 1.

was performed with arginine and insulin (Fig. 4) and with physiological responses as shown in Fig. 1 and 2. After a specific research application, growth hormone issue was approved and administered in a dose of $2.5 \mathrm{mg}$ intramuscularly three times weekly. His subsequent growth rate has been $7.5 \mathrm{~cm} /$ year (Fig 5). Bone age after 4 months of HGH therapy was 7.5 years with a chronological age of $12 \cdot 6$ years. After 12 months of HGH therapy his bone age had only advanced to $8 \cdot 3$ years with a chronological age of 13.35 years and a height age of 9.5 years. Testicular size remained at $2 \mathrm{ml}$ right and left and plasma testosterone was at prepubertal levels. His weight increased by $4 \cdot 7 \mathrm{~kg}$ to $29 \cdot 4 \mathrm{~kg}$.

Case 2. This boy was referred at age 16 years for evaluation of short stature $(142 \mathrm{~cm})$. He had a normal term gestation, and was delivered by caesarean section for disproportion. His verified pretreatment growth rate was $2 \mathrm{~cm} /$ year over the preceding 2 years. Milestones were all slightly delayed. Maternal and paternal heights were 160 and $172 \mathrm{~cm}$, respectively. He had symmetrical dwarfism, mild obesity $(50 \mathrm{~kg}$ ), and testicular size (Prader) of $10 \mathrm{ml}$ and $7 \mathrm{ml}$. Serum thyroxine was $9.4 \mu \mathrm{g} / 100 \mathrm{ml}$, and bone age was 14 years with 

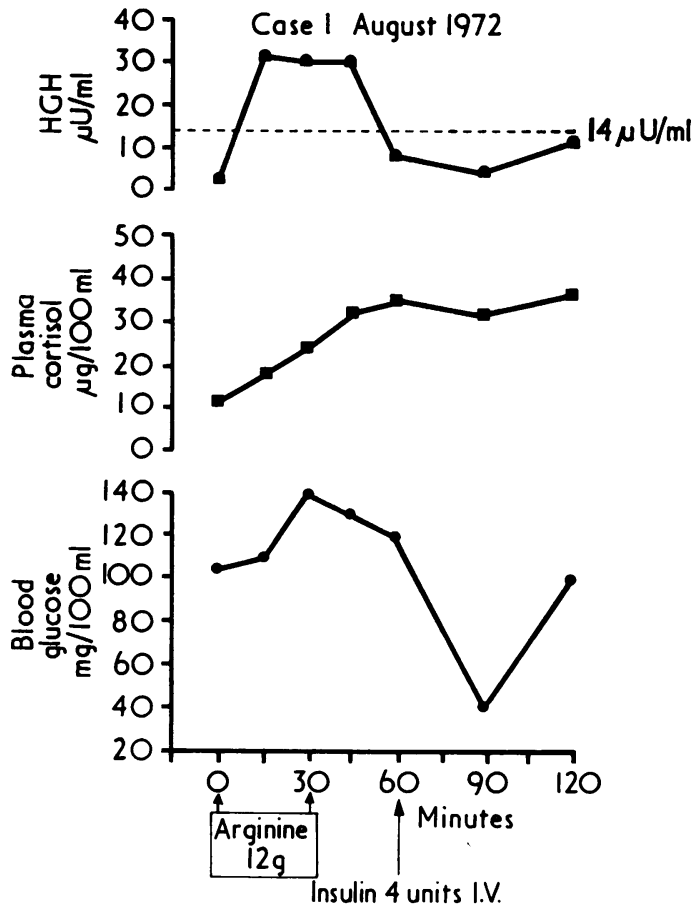

FIG. 4.-Arginine-insulin hypoglycaemia test in Case. 1.

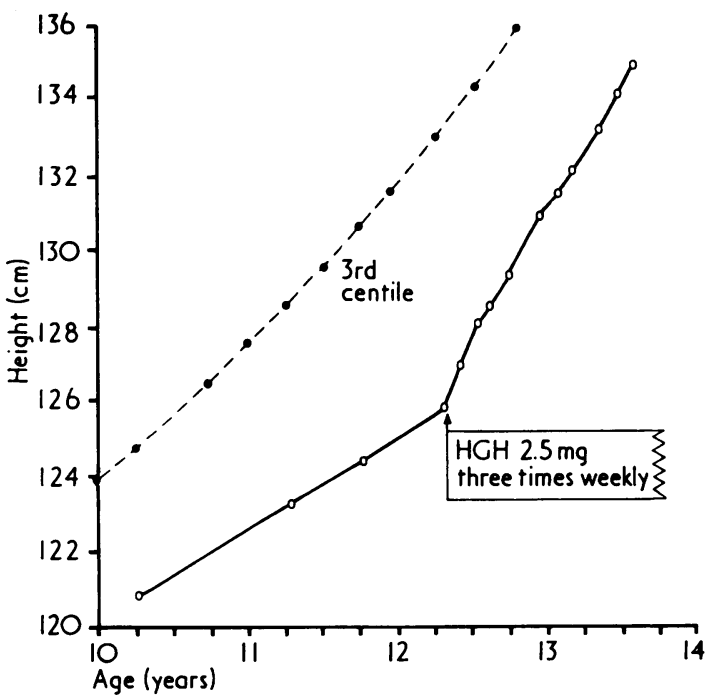

FIG. 5.-Growth chart of Case 1.

a height age of $11 \cdot 25$ years. Plasma testosterone was $278 \mathrm{ng} / 100 \mathrm{ml}$ (normal 450-960). A fasting level $\mathrm{HGH}$ of $2 \mu \mathrm{U} / \mathrm{ml}$ stimulated to greater than $50 \mu \mathrm{U} / \mathrm{ml}$ with both arginine and insulin (with a minimum blood glucose of $15 \mathrm{mg} / 100 \mathrm{ml}$ ). Exercise and sleep levels are shown in Fig. 1 and 2. During the 12 months of subsequent observation he gained only $2 \mathrm{~cm}$ in height. On the basis of special application, a research issue of HGH was approved and was administered in a dose of $2.5 \mathrm{mg}$ three times weekly. Bone age at onset of treatment was 15 years. In the first 6 months he grew $3 \mathrm{~cm}$ and over the next 6 months a further 1 $\mathrm{cm}$. As knee epiphyses had fused by this time and no further growth was shown, HGH was stopped.

\section{Discussion}

In this study sleep was shown to be as effective as combined arginine and insulin in eliciting normal growth hormone release. Furthermore, in one subject with subnormal HGH response to these pharmacological stimuli, both sleep and exercise elicited normal responses, and the patient has subsequently shown a growth velocity strikingly enhanced by a short course of gonadotrophin, in a manner typical of simple delayed puberty. The overall findings agree, both qualitatively and quantitatively, with those of Mace, Gotlin and Beck (1972). Although exercise produced HGH levels exceeding $14 \mu \mathrm{U} / \mathrm{ml}$ in only $50 \%$ of cases who were not $\mathrm{HGH}$ deficient, in agreement with data of Okada et al. (1972), the ease of performance is such that discomfort of hospitalization and multiple venepunctures can be avoided in a significant proportion of short subjects. An abnormal exercise response can be followed logically by assessment of a single sleeping HGH level using relatively accessible equipment, and more complex and uncomfortable procedures can consequently be reserved for confirmation in the comparatively small group of nonresponders to physiological stimuli.

Of great concern has been the possibility that normal responses to the pharmacological stimuli of arginine and hypoglycaemia might preclude a patient from receiving therapeutic $\mathrm{HGH}$ in situations where it might prove effective. Case 1 shows that normal HGH levels with pharmacological stimuli do not exclude a growth response to HGH administration. Such an entity was suggested by Tanner et al. (1971) and a similar response to that seen in Case 1 has been described by Eastman and Lazarus (1973) in a patient with a past history of craniopharyngioma. In Case 1 the striking and continued growth response to $\mathrm{HGH}$ is itself significant evidence of $\mathrm{HGH}$ deficiency. A pubertal growth spurt cannot be sustained as an explanation for this increment in height velocity, since bone maturation during therapy occurred at a normal rate. There were during this time no other signs 
of pubertal development nor any rise in the plasma testosterone. No other medication was given during this period. Whether the low levels of exercising and sleeping serum $\mathrm{HGH}$ reflect true physiological growth hormone deficiency is difficult to define, since a series of integrated 24-hour growth hormone secretion studies was not performed. However, with the resemblance to the case of Eastman and Lazarus (1973) it seems likely that additional cases will be identified if both physiological and pharmacological tests are performed in patients with short stature.

The importance of identifying such cases is evident, since up to the present time these patients would have been diagnosed as 'constitutional short stature' with the implication of nonresponsiveness to HGH therapy.

We thank the many physicians, especially Dr. M. S. Rice, for referring patients for evaluation and treatment, and the Commonwealth Human Pituitary Advisory Committee for the supply of therapeutic human growth hormone.

\section{REFERENCES}

Buckler, J. M. H. (1972). Exercise as a screening test for growth hormone release. Acta Endocrinologica, 69, 219

Dement, W., and Kleitman, N. (1957). Cyclical variations in EEG during sleep and their relation to eye movements, body motility and dreaming. Electroencephalography and Clinical Neurophysiology, 9, 673 .

Eastman, C. J., and Lazarus, L. (1973). Growth hormone release during sleep in growth retarded children. Archives of Disease in Childhood, 48, 502 .

Kaplan, S. L., Abrams, C. A. L., Bell, J. J., Conte, F. A., and Grumbach, M. M. (1968). Growth and growth hormone. Pediatric Research, 2, 43.

Mace, J. W., Gotlin, R. W., and Beck, P. (1972). Sleep related human growth hormone release: a test of physiologic growth hormone secretion in children. fournal of Clinical Endocrinology and Metabolsim, 34, 339.

Merrimee, T. J., Rabinowitz, D., Riggs, L., Burgess, J. A., Rimoin, D. L., and McKusick, V. A. (1967). Plasma growth hormone after arginine infusion. New England fournal of Medicine, 276, 434.

Mitchell, M. L., Byrne, M. J. and Silver, J. (1969). Growthhormone release by glucagon. Lancet, 1, 289.

Murphy, B. E. P. (1967). Some studies of the protein-binding of steroids and their application to the routine micro and ultramicro measurement of various steroids in body fluids by competitive protein-binding radioassay. Fournal of Clinical Endocrinology and Metabolism, 27, 973.
Okada, Y., Hikita, T., Ishitobi, K., Wada, M., Santo, Y., and Harada, Y. (1972). Human growth hormone secretion after exercise and oral glucose administration in patients with short stature. Fournal of Clinical Endocrinology and Metabolism, 34, 1055.

Penny, R., Blizzard, R. M., and Davis, W. T. (1969). Sequential arginine and insulin tolerance tests on the same day. Fournal of Clinical Endocrinology and Metabolism, 29, 1499.

Roth, J., Glick, S. M., Yalow, R. S., and Berson, S. A. (1963). Hypoglycaemia: a potent stimulus to secretion of growth hormone. Science, 140, 982.

Takahashi, Y., Kipnis, D. M., and Daughaday, W. H. (1968). Growth hormone secretion during sleep. Fournal of Clinical Investigation, 47, 2079.

Tanner, J. M., Whitehouse, R. H., Hughes, P. C. R., and Vince, F. P. (1971). Effect of human growth hormone treatment for 1 to 7 years on growth of 100 children, with growth hormone deficiency, low birthweight, inherited smallness, Turner's syndrome, and other complaints. Archives of Disease in Childhood, 46, 745

Tanner, J. M., Whitehouse, R. H., and Takaishi, M. (1966). Standards from birth to maturity for height, weight, height velocity, and weight velocity: British children, 1965. Archives of Disease in Childhood, 41, 454, 613.

Weldon, V. V., Gupta, S. K., Haymond, M. W., Pagliara, A. S., Jacobs, L. S., and Daughaday, W. H. (1973). The use of L-dopa in the diagnosis of hyposomatotropism in children fournal of Clinical Endocrinology and Metabolism, 36, 42.

Correspondence to Dr. P. H. Wise, Endocrine Unit, Royal Adelaide Hospital, Adelaide, South Australia 5000.

\section{Addendum}

Since this report was submitted for publication, and based on the concept that HGH levels up to $20 \mu \mathrm{U} / \mathrm{ml}$ may still reflect partial HGH deficiency (Tanner et al., 1971), a further subject with selective impairment of HGH release to physiological stimuli has received a therapeutic trial. He was aged 12.4 years at the start of treatment, with a height of $122 \mathrm{~cm}$, bone age of 8.5 years, and with a pretreatment growth rate (over 12 months) of $3.8 \mathrm{~cm} /$ year. He was one of the subjects classified as delayed puberty in the original study, on the basis of a $14 \mu \mathrm{U} / \mathrm{ml}$ discriminatory level. He had physiological response to sleep and exercise, indicated in Fig. 1 and 2 as *. Maximal response to arginine/insulin provocation was $41 \mu \mathrm{U} / \mathrm{ml}$. During therapy with HGH $5 \mathrm{mg}$ twice weekly, growth rate over the first 9 months of therapy has been $7.5 \mathrm{~cm} /$ year. This provides validation for the concept of a serum HGH level of $20 \mu \mathrm{U} / \mathrm{ml}$, representing the lower limit of normal response to any $\mathrm{HGH}$ releasing stimulus. 